\title{
Contents Vol. 49, 1986
}

JÊ fjü f] Journal of Stereotactic and Functional Neurosurgery

\section{Applied Neurophysiology}

Official Journal of the World Society for Stereotactic and Functional Neurosurgery Official Journal of the American Society for Stereotactic and Functional Neurosurgery

Founded 1938 as 'Confinia Neurologica' by E.A. Spiegel

Editor

Ph.L. Gildenberg, Houston, Tex.

Assistant Editor

Patricia O. Franklin, Houston, Tex. 
Editorial Board

M. Dimitrijevic, Houston, Tex. E. Eidelberg, San Antonio, Tex. R.G. Grossman, Houston, Tex.

E. Hitchcock, Birmingham

E.I. Kandel, Moscow

P.J. Kelly, Rochester L. Laitinen, Umea D.M. Long, Baltimore, Md. R. Marino, Sao Paulo

F. Mundinger, Freiburg i.Br. 
H. Narabayashi, Tokyo

B.S. Nashold, Jr., Durham, N.C.

G. Ojemann, Seattle, Wash.

T.S. Roberts, Seattle

G.S. Rossi, Rome

J. Siegfried, Zurich

A. Struppler, Munich

R.R. Tasker, Toronto

J.U. Toglia, Philadelphia, Pa.

J.M. Van Buren, Chapel Hill, N.C.

\section{$\mathrm{mmm}$}



S. Karger $\bullet$ Medical and Scientific Publishers

Basel $\bullet$ München $\bullet$ Paris $\bullet$ London $\bullet$ New York $\bullet$ New Delhi $\bullet$ Singapore $\bullet$ Tokyo • Sydney

Drug Dosage

The authors and the publisher have exerted every effort to ensure that drug selection and dosage set forth in this text are in accord with current recommendations and practice at the time of publication. However, in view of ongoing research, changes in government regulations, and the constant flow of information relating to drug therapy and drug reactions, the reader is urged to check the package insert for each drug for any change in indica-tions and dosage and for added warnings and precau-tions. This is particularly important when the recommended agent is a new and/or infrequently employed drug. 
All rights reserved.

No part of this publication may be translated into other languages, reproduced or utilized in any fonn or by any means, electronic or mechanical, including photocopy-ing, recording, microcopying, orby any information stor-age and retrieval system, without permission in writing from the publisher or, in the case of photocopying, direct payment of a specified fee to the Copyright Clearance Center (see 'Information for Readers and Subscribers').

(C) Copyright 1987 by

S. Karger AG, P.O. Box, CH-4009 Basel (Switzerland)

Printed in Switzerland by

National Zeitung und Basler Nachrichten, Basel 


\section{Contents Vol. 49,1986}

No. 1-2 Simplified Method to Implant Chronic Stimulating Electrode in the Gasserian Ganglion.

Technical Note

Spaziante, R.; Ferone, A.; Cappabianca, P

Electrical Stimulation in Multiple Sclerosis. Comparison of Transcutaneous Electrical

Stimulation and Epidural Spinal Cord Stimulation

Fredriksen, T.A.; Bergmann, S.; Hesselberg, J.P.; Stolt-Nielsen, A.; Ringkjob, R.;

Sjaastad, 0 4

Functional Amaurosis: Diagnostic Value of Electronystagmography

Toglia, J.U 25

Use of Antidromic Evoked Potentials in Placement of Dorsal Cord Disc Electrodes

Yingling, CD.; Hosobuchi, Y 36

Influence of Long-Term Low Direct Current on Rat Ischiadic Nerves

Rosenkranz, D.; Fenzl, G.; Holle, J.; Lack, W.; Losert, U.; Thoma, H 42

CT-Compatible System for Stereotactic Biopsy and Brachytherapy of Infratentorial Tumors

Dyck, P.; Bouzaglou, A.; Solti-Bohman, L.G.; Gruskin, P 53

Respiratory Changes after Stereotactic High Cervical Cord Lesions for Pain

Lema, J.A.; Hitchcock, E

Spinal Cord Stimulation Revisited: Psychological Effects

Levita, E.; Sorkin, B.A.; Waltz, J.M

Changes in Regional Cerebral Blood Flow and Oxygen Metabolism Following Ventrolateral

Thalamotomy in Parkinson Syndrome as Revealed by Positron Emission Tomography

Katayama, Y.; Tsubokawa, T.; Tsukiyama, T.; Hirayama, T 76

Transcutaneous Nerve Stimulation. Frequency and Waveform Specificity in Humans

Katims, J.J.; Long, D.M.; Ng, L.K.Y 86

Abstracts

24th Annual Meeting of the Japanese Society for Stereotactic and Functional Neurosurgery

Nagasaki, October 1985; Prof. Kazuo Mori

93

No. 3 Long-Term Follow-Up Study of Rostral Mesencephalic Reticulotomy for Pain Relief -

Report of 34 Cases

Amano, K.; Kawamura, H.; Tanikawa, T.; Kawabatake, H.; Notani, M.; Iseki, H.;

Shiwaku, T.; Nagao, T.; Iwata, Y.; Taira, T.; Umezawa, Y.; Simizu, T.; Kitamura, K. 105 Responses of Raphe-Spinal Neurons to Stimulation of the Pontine Parabrachial Region

Producing Behavioral Nociceptive Suppression in the Cat

Katayama, Y.; Tsubokawa, T.; Maejima, S.; Yamamoto, T 112

Response of Single Alpha Motoneurons to High-Frequency Pulse Trains. Firing Behavior and Conduction Block Phenomenon

Bowman, B.R.; McNeal, D.R 121

Spinal Cord Stimulation Affects the Central Mechanisms of Regulation of Heart Rate

Meglio, M.; Cioni, B.; Rossi, G.F.; Sandric, S.; Santarelli, P 
Contents

A Simple in vitro Method to Study the Trigeminal Ganglion

Loveren, H.R. van; Haas, H.L.; Greene, R.W.; Siegfried, J 147

Influence of Stimulus Frequency and Probe Size on Vibration-Induced Alleviation of Acute

Orofacial Pain

Hansson, P.; Ekblom, A 155

Stimulation of the Spinal Cord in the Treatment of Traumatic Injuries of Cervical Spine

Kiwerski, J $\quad 166$

Announcement 172

No. 4 Memorial Essays

Lars Leksell - a Portrait by a Friend

Backlund, E.-0 173

Irving S. Cooper, MD, MS, PhD, FACS

Upton, A.R.M $\quad .182$

Original Papers

Gouda Frame Redesigned Specifically for Computed Tomographic Compatibility

Gouda, K.I.; Freidberg, S.R.; Baker, R.A.; Larsen, CR.; Silverman, M.L

Stereotactic Computed Tomographic-Guided Functional Neurosurgery Using the Redesigned Gouda Frame

Gouda, K.I.; Freidberg, S.R.; Fager, CA.; Tarlov, C; Baker, R.A.; Larsen, CR.; Kott, S.H. 201

Anterior Zygomatic Electrodes: A Special Electrode for the Study of Temporal Lobe Epilepsy

Manzano, G.M.; Ragazzo, P.C.; Tavares, S.M.; Marino, R., Jr. 213

Effect of Epidural Spinal Cord Stimulation on the Activity of Lateral Vestibular Nucleus

Neurons in the Cat

Culic, M.; Jeftinija, S

218

Effects of Thalamic Sensory Relay Nucleus Stimulation on the Jaw-Opening Reflex in

Response to Tooth-Pulp Stimulation in the Cat

Tsubokawa, T.; Katayama, Y.; Hirayama, T.; Yamamoto, T.; Nishimoto, Hx

No. 5 Sensory-Motor Integration. Implications for Neurological Disease

Summaries of the Symposium held in Munich, April 20-24, 1985 Editors: A. Struppler, Munich, A. Weindl, Munich, P.L. Gildenberg, Houston, Tex., P.O. Franklin, Houston, Tex.

Somatosensory Activity Relevant for Motor Output

Gandevia, S.C 241

Sensory Input Modifying Central Motor Actions

Henn, V 251

Muscles and Their Neural Control

Bruggencate, G. ten $\quad . i^{*} / \mathrm{m}^{\prime}$. Jftl 256

Long Loop Reflexes: Concepts and Consequences

Noth, J Jtj/SL^ir. .*R 262

Motor Functions of the Basal Ganglia

Wiesendanger, $M \quad j £ j \| \quad 269$

Effects of Growth, Degeneration and Regeneration on the Sensory Motor System

Mackel, R 278 


\section{Contents V}

No. 6 Abstracts

25th Annual Meeting of the Japanese Society for Stereotactic and Functional Neurosurgery

Tokyo, September 1986; Prof. Buichi Ishijima 285

Original Papers Computerized Tomography-Guided Stereotactic Dentatotomy

Weigel, K.; Mundinger, F 301

Enhancement of Voluntary Motor Function Following Spinal Cord Stimulation - Case

Study

Barolat, G.; Myklebust, J.B.; Wenninger, W

Epidural Recordings of Electrical Events Produced in the Spinal Cord by Segmental, Ascending and Descending Volleys

Cioni, B.; Meglio, M

315

Somatosensory Evoked Potentials in the Ventrolateral Thalamus

Birk, P.; Riescher, H.; Struppler, A.; Keidel, M 327

Reproducibility of Repeated Mountings of a Noninvasive CT/MRI Stereoadapter

Hariz, M.I.; Eriksson, A.T 336

Book Reviews $\quad 348$

Author Index $\quad 350$

Subject Index 353 